\title{
Preconcentration of Sn in Real Water Samples by Solid Phase Extraction Based on the Use of Helvella leucopus as a Fungal Biomass Prior to its Determination by ICP-OES
}

\author{
Ersin Kılınça*, Abdurrahman Dündar ${ }^{\mathrm{b}}$, Sadin Özdemir ${ }^{\mathrm{c}}$, and Veysi Okumuş ${ }^{\mathrm{c}}$ \\ ${ }^{a}$ Medical Laboratory Techniques, Vocational High School of Healthcare Studies \\ Mardin Artuklu University, 47200 Mardin, Turkey \\ ${ }^{b}$ Health Services, Vocational High School, Medical Marketing and Promotion Programme, \\ Mardin Artuklu University, 47200 Mardin, Turkey \\ ${ }^{c}$ Department of Biology, Faculty of Art and Science, Siirt University, 56100 Siirt, Turkey
}

\section{INTRODUCTION}

It has been reported that the toxicity and biological activity of tin (Sn) depends on its oxidation states (mainly $\mathrm{Sn}^{2+}$ and $\left.\mathrm{Sn}^{4+}\right)(1,2)$.

Among them, $\mathrm{Sn}^{2+}$ is reported to be more toxic than $\mathrm{Sn}^{4+}$. In addition, organotin compounds such as tributyltin, dibutyltin, and monobutyltin are also toxic (1). The concentration of total $\mathrm{Sn}$ in water samples is known to be at the $\mathrm{ng} \mathrm{mL}^{-1}$ levels (3). From this perspective, the development of sensitive and selective analytical methods for the preconcentration of $\mathrm{Sn}^{2+}$ is an important issue in analytical and environmental chemistry. The direct determination of Sn by flame atomic absorption spectrometry (FAAS) and inductively coupled plasma optical emission spectrometry (ICP-OES) is limited due to the poor sensitivity of these techniques and a preconcentration procedure is generally required before instrumental detection. Cloud point extraction (CPE) $(4,5)$, solid phase extraction (SPE) (1, 6-8), coprecipitation (3), and liquid-liquid extraction (9) allow the detection of tin. However, they require the use of chemical ligands and time-consuming steps such as centrifugation. Hydride generation for volatile stannane formation (10) and the electrothermal atomizer (11) are also employed for ultratrace deter-

*Corresponding autbor.

E-mail: kilincersin@gmail.com

Tel: 0090 (412) 24885 50-3054

Fax: 0090 (412) 2488300

\section{ABSTRACT}

Recently, biosorbents of biological origin such as fungus, algae, and bacteria have found special application as packing material in solid phase extraction (SPE). In this study, an alternative SPE method was developed and validated for the preconcentration of $\mathrm{Sn}$ prior to its determination by inductively coupled plasma optical emission spectrometry (ICPOES). Helvella leucopus, a fungal biomass, was used as the biosorbent in the column studies. Experimental parameters, such as $\mathrm{pH}$ and flow rate of the solution, amounts of biosorbent and resin, and volume of the sample solution which affects the analytical results, were investigated. Effects of possible interfering ions on the SPE preconcentration of Sn were investigated. The sensitivity of ICP-OES was improved 47.1 times for $\mathrm{Sn}$. The LOD and LOQ values were 0.06 and $0.21 \mathrm{ng} \mathrm{mL}^{-1}$, respectively. Linearity was obtained in the concentration range of $1.0-30 \mathrm{ng} \mathrm{mL}^{-1}$ for $\mathrm{Sn}$. The loading capacity of Helvella leucopus immobilized Amberlite XAD- 4 was $10.4 \mathrm{mg} \mathrm{g}^{-1}$. The concentrations of $\mathrm{Sn}$ in the water samples from the Tigris River were determined using the developed method and validated by analysis of the certified reference material NWTM-26.3 Fortified Water sample.

minations of Sn. SPE is the most common technique generally used for the preconcentration of metal ions, including toxic ions in a vari- ety of samples. The advantages and disadvantages of the preconcentration techniques were evaluated in a recent review in detail (12). As an alternative to chemical ligands, the use of bacterial biomass materials has become of special interest due to their efficiency, surface functionality, environmentally friendly properties, and applicability for the preconcentrationof metal ions. In addition, synthesis procedures for ligands are eliminated when biomass is used as the sorbent. However, methods for the preconcentration of Sn were focused on the sorption of batch conditions (13), SPE on ligands (6-8), CPE (2, 4, 5, 14), coprecipitation (3), and solvent extraction (9). Reports on the use of preconcentration methods for Sn using biomass are still very few.

In our research group, bacterial biomass immobilized to resin was used as a solid phase sorbent for the preconcentration of metal ions. In previous reports, Geobacillus thermoleovorans subsp. stromboliensis, immobilized on Amberlite XAD-4, was used for the preconcentrations of $\mathrm{Cd}$ and $\mathrm{Ni}$ before their detections by FAAS (15). Bacillus sp., immobilized on Amberlite XAD- 4 resin, was used as a biosorbent for solid phase preconcentration of Th prior to UV-Vis spectrometry determination (16). Geobacillus thermoleovorans, immobilized on Amberlite XAD-4 resin, was used as a biosorbent for solid phase preconcentration of $\mathrm{U}^{6+}$ prior to its spectrophotometric determination (17). $\mathrm{Cd}^{2+}$ and $\mathrm{Co}^{2+}$ 
were preconcentrated on Pleurotuseryngii, immobilized on Amberlite XAD-16, and their concentrations were determined by ICP-OES (18). Since preconcentration of Sn by the SPE method based on the use of fungal biomass is limited, in this study we focused on the development of a sensitive and selective preconcentration method. Helvella leucopus was used as the fungal biomass for the preconcentration of Sn prior to its determination by ICP-OES. Important experimental parameters were optimized throughout the study.

\section{EXPERIMENTAL}

\section{Instrumentation}

A Model Optima ${ }^{\mathrm{TM}} 2100$ DV inductively coupled plasmaoptical emission spectrometer (ICP-OES) (PerkinElmer, Inc., Shelton, CT, USA) was used for the determination of $\mathrm{Sn}$ at the wavelength of $189.927 \mathrm{~nm}$. The operating conditions of the ICP-OES for the determination of Sn were given in our previous study and are also listed in Table I (18). A Model MPC 227 digital pH meter (Mettler-Toledo Co., Columbus, $\mathrm{OH}$, USA) was used for adjustment of the acidity of the solutions. Filtration columns $(1.0 \mathrm{~cm}$ $\times 10.0 \mathrm{~cm}$ ), equipped with polypropylene frits, were used for solid phase extraction (SPE). A Model Marlow 323 peristaltic pump (Waters Co., Milford, MA, USA) was used for passing the solutions through the column.

\section{Standard Solutions and Reagents}

Stock solutions of Sn were prepared from its individual stock solution at the concentration of $1000 \mu \mathrm{g} \mathrm{mL}^{-1}$ (High Purity Standards, Charleston, SC, USA) with doubly distilled. This solution was used for the standards at lower concentrations. All glass materials were washed with $1.0 \mathrm{~mol} \mathrm{~L}^{-1}$ of nitric acid and then with doubly distilled water before use. $\mathrm{HNO}_{3}$ (65\%) and $\mathrm{H}_{2} \mathrm{O}_{2}$ (35\%) were supplied from E. Merck (Darmstadt, Germany) and used in the digestion procedures. Amberlite XAD-4 (Sigma Chemical, USA, 20-40 mesh, $780 \mathrm{~m}^{2} / \mathrm{g}$ ) was used as a substrate for the immobilization of Helvella leucopus and $\mathrm{HCl}$ ( $4.0 \mathrm{~mol} \mathrm{~L}^{-1}$ ) was used to remove the contaminants from the Amberlite XAD-4. The resin was first rinsed with distilled water until its $\mathrm{pH}$ was neutral, then with an ethanol-water (1:1) solution, finally with distilled water again, and stored in a polyethylene bottle. Certified reference material NWTM26.3 Fortified Water sample was purchased from LGC (Middlesex, UK).

\section{Preparation of SPE Column}

In this study, Helvella leucopus, collected from Siirt, Turkey, was used as a biosorbent for the preconcentration of $\mathrm{Sn}$. To remove the dirt from the biosorbent, it was washed twice with distilled water. After washing, the biosorbent was dried at $25^{\circ} \mathrm{C}$. The dried fungus was granulated in a porcelain mortar to achieve a fine powder, then ovendried at $80{ }^{\circ} \mathrm{C}$ for 24 hours to assess the complete death of the dried cells. Finally, the cells were inoculated to malt agar at $25^{\circ} \mathrm{C}$ for 24 hours. The absence of mycelia of Helvella leucopus showed positive results, meaning the complete death of the fungus. The SPE column was prepared by a procedure from our previous studies (15, 17). A 150-mg amount of dry powder biosorbent was mixed with $750 \mathrm{mg}$ Amberlite XAD-4. After immobilization of the biosorbent to resin, it was sieved to get sizes of 20-60 mesh and packed in a solid phase column $(1.0 \mathrm{~cm} \times 10 \mathrm{~cm})$. Before use, approximately $10 \mathrm{~mL}$ of $1.0 \mathrm{~mol} \mathrm{~L}^{-1} \mathrm{HCl}$ solution and $10 \mathrm{~mL}$ of doubly distilled deionized water were passed through the column for conditioning and cleaning.

TABLE I

ICP-OES Operating Conditions

\begin{tabular}{ll}
\hline Parameters & \\
\hline RF power & $1450 \mathrm{~W}$ \\
Plasma gas flow rate & $15 \mathrm{~L} / \mathrm{min}$ \\
Auxiliary gas flow rate & $0.2 \mathrm{~L} / \mathrm{min}$ \\
Nebulizer gas flow rate & $0.8 \mathrm{~L} / \mathrm{min}$ \\
Sample flow rate & $1.5 \mathrm{~L} / \mathrm{min}$ \\
View mode & Axial-Radial \\
Read & Peak area \\
Source equilibration time & 15 sec \\
Read delay & 60 sec \\
Replicates & 3 \\
Background correction & 2 -point (manual point correction) \\
Spray chamber & Scott-type spray chamber \\
Nebulizer & Cross-Flow GemTip Nebulizer \\
& (HF resistant) \\
Detector & CCD \\
Purge gas & Nitrogen \\
Shear gas & Air \\
Gas & Argon \\
Analytical wavelength & Sn 189.927 nm \\
\hline
\end{tabular}


Loading Capacity of Helvella leucopus Immobilized on XAD-4

The biosorption capacity of Helvella leucopus immobilized on $\mathrm{XAD}-4$ resin for $\mathrm{Sn}^{2+}$ was found from experiments in batch conditions. An amount of $150 \mathrm{mg}$ of Helvella leucopus, immobilized on $750 \mathrm{mg}$ of Amberlite XAD-4, was added to 250-mL Erlenmeyer flasks containing $100 \mathrm{~mL}$ of $100 \mathrm{mg} \mathrm{L}^{-1}$ of $\mathrm{Sn}^{2+}$, then it was agitated at $120 \mathrm{rpm}$ for two hours. The temperature was kept constant at $25^{\circ} \mathrm{C}$ during the batch adsorption studies. The immobilized biosorbents were then centrifuged at $10,000 \mathrm{rpm}$ for 10 minutes. The supernatant and pellet (after acid digestion by concentrated $\mathrm{HNO}_{3}$ acid) were used to determine the residual metal concentration by ICP-OES. The amount of biosorbed $\mathrm{Sn}^{2+}$ was calculated using the equation given in the literature (19) as follows:

$$
\mathrm{q}_{\mathrm{eq}}=\frac{\left(\mathrm{c}_{0}-\mathrm{c}_{\mathrm{eq}}\right) \mathrm{V}}{\mathrm{x}}
$$

where $c_{0}$ is the initial concentration of the solution, $\mathrm{c}_{\mathrm{eq}}$ the concentration of the solution at equilibrium, $\mathrm{V}$ the volume of the solution, and $\mathrm{x}$ the mass of the biosorbent.

\section{Preparation of Samples for SPE Procedure}

The batch process was used to determine the biosorption capacity of Helvella leucopus, immobilized on XAD-4 resin. A 150-mg amount of Helvella leucopus, immobilized on $750 \mathrm{mg}$ of XAD-4 resin, was added to $100 \mathrm{~mL}$ of solution containing $100 \mu \mathrm{g} \mathrm{mL}^{-1}$ of $\mathrm{Sn}^{2+}$ solution at $\mathrm{pH}$ 6.0, and then incubated by shaking at $120 \mathrm{rpm}$ for two hours. The biosorption capacity of immobilized Helvella leucopus was found at $10.4 \mathrm{mg} \mathrm{Sn}^{2+}$ per $\mathrm{g}$ of biosorbent.

The water samples were collected from three different locations of the Tigris River (Hevsel, Ongözlü, and Dicle Köprü). Before sampling, the polyethylene sample containers were cleaned with $1.0 \mathrm{~mol} \mathrm{~L}^{-1}$ of $\mathrm{HNO}_{3}$ and rinsed with distilled water. A $1.0 \mathrm{~L}$ amount of the water sample was added and filtered through a $0.45 \mu \mathrm{m}$ membrane filter. Then, $1.0 \mathrm{~mL}$ of $\mathrm{HNO}_{3}$ was added to prevent precipitation.

\section{RESULTS AND DISCUSSION}

\section{Effects of pH}

It is well known that with SPE experiments the sample solution $\mathrm{pH}$ is an important parameter for quantitative recoveries of the analyte metal ions on the biosorbent $(20,21)$. When the solution $\mathrm{pH}$ decreases, the protons compete with the metal ions for the binding sites of the biosorbent; but when the $\mathrm{pH}$ increases, the hydroxide will complex and precipitate the metal ions. From that point of view, the solution $\mathrm{pH}$ is the first parameter that should be optimized (22).

As shown in Figure 1, the effects of solution $\mathrm{pH}$ on the recoveries of $\mathrm{Sn}^{2+}$ on Helvella leucopus, immobilized on XAD- 4 resin, were studied between the 2.0-8.0 range. It was found that $10.0 \mathrm{ng} \mathrm{mL}^{-1}$ of $\mathrm{Sn}^{2+}$ was quantitatively recovered at the $\mathrm{pH}$ range of 4.0-7.0. When the solution $\mathrm{pH}$ increased from 2.0 to 5.0, the $\mathrm{Sn}^{2+}$ recovery increased from $29.1 \%$ to $93.9 \%$, respectively. These values may be due to the competition between the protons and analytes for the biosorption sites of the

\section{Atomic Apectroscopy $\bigcirc$ Vol. 34(4), July/August 2013}

immobilized biosorbent (18). Optimum recovery of $\mathrm{Sn}^{2+}$ was achieved at $\mathrm{pH}$ 6.0. On the other hand, when the solution $\mathrm{pH}$ increased from 6.0 to 8.0, the percentage of $\mathrm{Sn}^{2+}$ recovery decreased from $100 \%$ to $94.3 \%$ for Helvella leucopus, immobilized on the XAD- 4 resin, respectively. The decrease in percentage of $\mathrm{Sn}^{2+}$ recovery at higher $\mathrm{pH}$ values may be attributed to the formation of anionic hydroxide complexes and to the competition between the cell wall and ammonia (23). Subsequent studies were carried out at an initial $\mathrm{pH}$ of 6.0.

\section{Effect of Sample and Elution Flow Rates}

The effect of the quantitative uptakes of the analyte metal ions in solid phase extraction processes depends on the flow rates of the sample and eluent solutions (24). The flow rate of the sample and elution solution is one of the most important parameters affecting both the uptake of the analyte metal ions and controlling the time of analysis (25). The effect of sample and eluent flow rate on the recovery of $10.0 \mathrm{ng} \mathrm{mL}^{-1}$ of $\mathrm{Sn}^{2+}$ is shown in Table II. It was found that in the flow rate range of 1.0-6.0 $\mathrm{mL} \mathrm{min}^{-1}$, the uptake of analyte metal ions was affected by the immobilized biosorbent. The optimum flow rate of the solution was

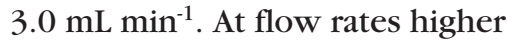

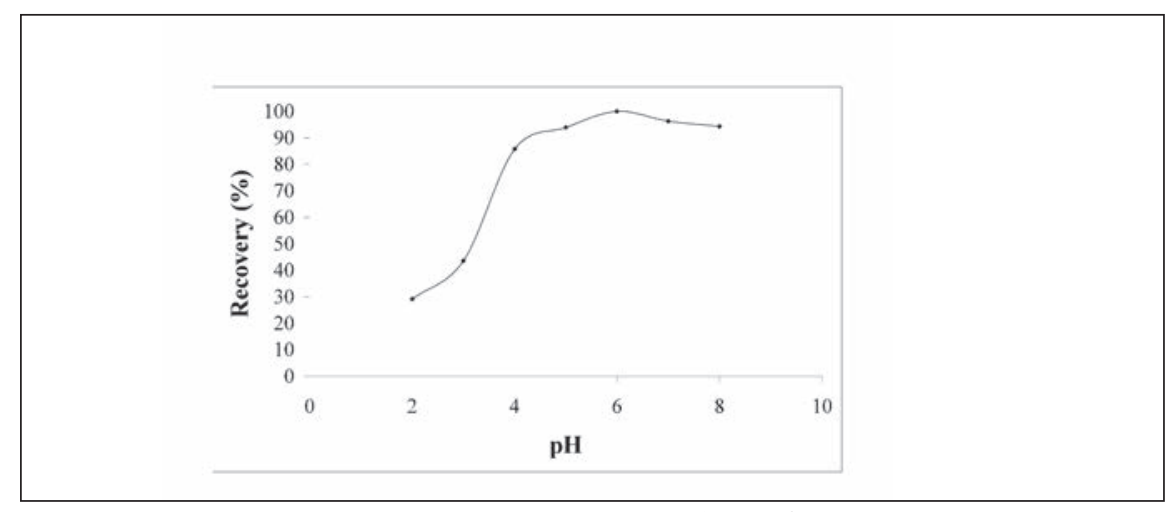

Fig. 1. Effect of $\mathrm{pH}$ on the recovery of $10.0 \mathrm{ng} \mathrm{mL}^{-1}$ of $\mathrm{Sn}^{2+}$. 
than $3.0 \mathrm{~mL} \mathrm{~min}^{-1}$, the uptake efficiency decreased because of insufficient phase contact between the $\mathrm{Sn}^{2+}$ and the binding sites of the biosorbent (24).

The effect of eluent $\left(1.0 \mathrm{~mol} \mathrm{~L}^{-1}\right.$ HCI) flow rate on the recovery of $10.0 \mathrm{ng} \mathrm{mL}^{-1}$ of $\mathrm{Sn}^{2+}$ was studied at the concentration of $1.0 \mathrm{~mol} \mathrm{~L}^{-1}$ HCI $(5.0 \mathrm{~mL})$. Maximum uptake was obtained at flow rates between 1.0 and $2.0 \mathrm{~mL} \mathrm{~min}{ }^{-1}$. At eluent flow rates higher than $2.0 \mathrm{~mL} \mathrm{~min}^{-1}$, the uptake efficiency of $\mathrm{Sn}^{2+}$ ions was not quantitative. All subsequent studies were carried out at a flow rate of 3.0 and $2.0 \mathrm{~mL} \mathrm{~min}^{-1}$ for the sample and eluent solutions, respectively.

\section{Effect of Amount of Biosorbent and Resin}

The biosorbent and resin amount are one of the other important parameters for obtaining quantitative uptake of the analyte metal ions in solid phase extraction studies. It is obvious that with an increase in biosorbent, greater surface area and replaceable sites are available and thus the uptake of the analyte metal ions goes up (26). The effect of amount of biosorbent and resin dosage on the recovery of $10.0 \mathrm{ng} \mathrm{mL}^{-1}$ of $\mathrm{Sn}^{2+}$ can be seen in Table III. The results show that the optimum amount of biosorbent within the experimental range of 100 to $400 \mathrm{mg}$ was $300 \mathrm{mg}$, while $400 \mathrm{mg}$ did not increase the uptake efficiency. This may be due to the fact that a higher dose causes particle aggregates and interference or repulsive forces between the binding sites and, therefore, decreases the interaction of the metal ions with the biosorbent and reduces the total surface area of the biosorbent (27).

Support materials are required to have some physical adequacies such as high surface area, enough pore size to immobilization of biosorbent, and low particle size. In order to determine the effect of the dosage of XAD- 4 resin on the quantitative uptake of $\mathrm{Sn}^{2+}$, studies were conducted with XAD-4 resin ranging in the amount from 200 to $1250 \mathrm{mg}$. The results showed that maximum uptake of $\mathrm{Sn}^{2+}$ was achieved at the concentration of $10.0 \mathrm{ng} \mathrm{mL}^{-1}$ with an increase in
XAD-4 up to $750 \mathrm{mg}$. For further studies, $750 \mathrm{mg}$ of XAD- 4 was used because of the higher surface area at high dosage of biosorbent.

\section{Effect of Eluent Type and Concentration}

Non-destructive uptake is necessary for the regeneration of the biosorbent for reuse in successive biosorption and desorption cycles. To determine the non-destructive uptake, the concentration of eluent solution utilized for stripping the metals bound to the biosorbent surface must be as low as possible (28). Different concentrations of $\mathrm{HCl}$ and $\mathrm{HNO}_{3}$ were used for the eluate of $\mathrm{Sn}^{2+}$ from Helvella leucopus immobilized on XAD-4 resin. The experimental results in Figure 2 show that $1.0 \mathrm{~mol} \mathrm{~L}^{-1} \mathrm{HCI}$ was sufficient for quantitative elution

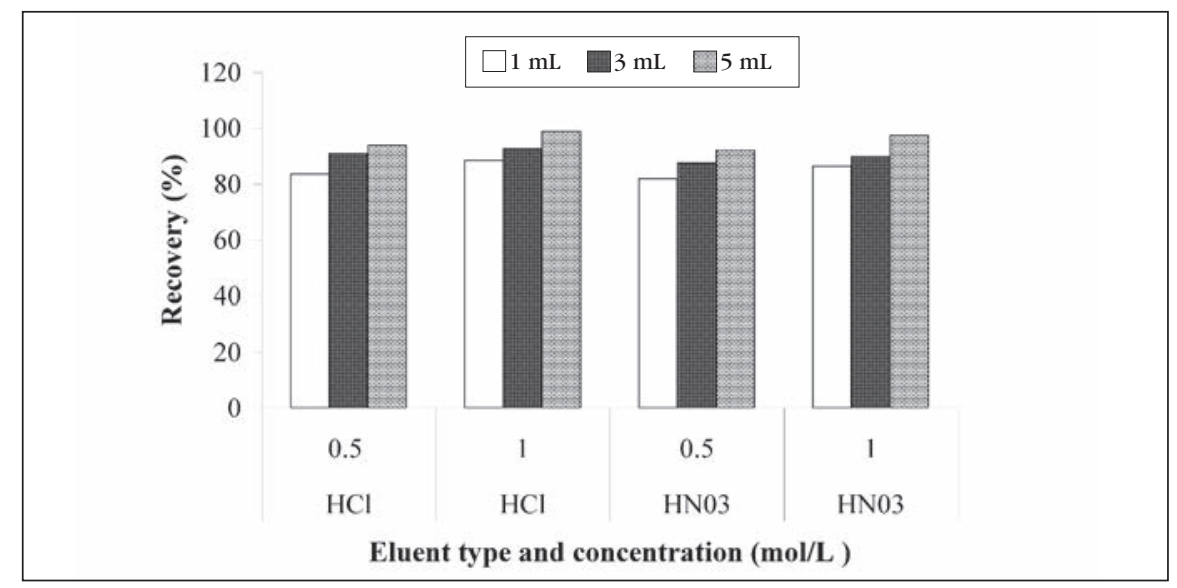

Fig. 2. Effect of the type and volume of elution solutions on the recovery of $10.0 \mathrm{ng} \mathrm{mL}^{-1}$ of $\mathrm{Sn}^{2+}$.

TABLE II

Effect of Flow Rate of Sample and Eluent Solution on Solid Phase Extraction of $10.0 \mathrm{ng} \mathrm{mL}^{-1} \mathrm{of} \mathrm{Sn}^{2+}$

\begin{tabular}{cccc}
\hline $\begin{array}{c}\text { Sample Flow } \\
\text { Rate }\left(\mathrm{mL} \mathrm{min} \mathrm{m}^{-1}\right)\end{array}$ & $\begin{array}{c}\text { Recovery } \\
(\%)\end{array}$ & $\begin{array}{c}\text { Eluent Flow } \\
\text { Rate }\left(\mathrm{mL} \mathrm{min} \mathrm{m}^{-1}\right)\end{array}$ & $\begin{array}{c}\text { Recovery } \\
(\%)\end{array}$ \\
\hline 1.0 & 99.3 & 1.0 & 98.9 \\
2.0 & 96.5 & 2.0 & 99.1 \\
3.0 & 98.8 & 3.0 & 96.8 \\
4.0 & 93.8 & 4.0 & 95.2 \\
5.0 & 86.2 & 5.0 & 86.1 \\
6.0 & 80.7 & 6.0 & 83.7 \\
\hline
\end{tabular}

TABLE III

Effect of Amounts of Biosorbent and Resin on the Recovery of $10.0 \mathrm{ng} \mathrm{mL}^{-1} \mathrm{of} \mathrm{Sn}^{2+}$

\begin{tabular}{cc|cc}
\hline $\begin{array}{c}\text { Amount of } \\
\text { Biosorbent (mg) }\end{array}$ & $\begin{array}{c}\text { Recovery } \\
(\%)\end{array}$ & $\begin{array}{c}\text { Amount } \\
\text { of Resin (mg) }\end{array}$ & $\begin{array}{c}\text { Recovery } \\
(\%)\end{array}$ \\
\hline 100 & 84.6 & 200 & 63.2 \\
150 & 90.4 & 300 & 72.4 \\
200 & 96.5 & 400 & 85.8 \\
250 & 97.1 & 500 & 92.7 \\
300 & 96.7 & 750 & 98.6 \\
350 & 95.1 & 1000 & 97.3 \\
400 & 95.0 & 1250 & 97.1 \\
\hline
\end{tabular}


(>95\%). The influence of eluent volume $\left(1.0-10 \mathrm{~mL}, 1.0 \mathrm{~mol} \mathrm{~L}^{-1}\right.$ $\mathrm{HCI}$ ) on the uptake of $10.0 \mathrm{ng} \mathrm{\textrm {mL } ^ { - 1 }}$ of $\mathrm{Sn}^{2+}$ by Helvella leucopus immobilized on XAD- 4 resin was studied. It was determined that quantitative uptakes were achieved for $\mathrm{Sn}^{2+}$ with $5.0 \mathrm{~mL}$ of $1.0 \mathrm{~mol} \mathrm{~L}^{-1} \mathrm{HCI}$ (98.8\%), which is the amount of eluent used in further studies.

\section{Effect of Sample Volume}

For preconcentration of metal ions in a real sample, the sample volume is important for obtaining high preconcentration factors (29). In order to deal with real samples containing very low concentrations of metal ions, trace metal ions or radionucleids, the maximum applicable sample volume must be determined (30). From that point of view, the influence of the sample

TABLE IV

Effect of Volume of Initial Solution on the Recovery of $10.0 \mathrm{ng} \mathrm{mL}^{-1}$ of $\mathrm{Sn}^{2+}$

\begin{tabular}{ccc}
\hline Volume & $\begin{array}{c}\text { Conc. } \\
\left(\mathrm{ng} \mathrm{mL}^{-1}\right)\end{array}$ & $\begin{array}{c}\text { Recovery } \\
(\%)\end{array}$ \\
\hline 25 & 100.0 & 100.0 \\
50 & 50.0 & 99.9 \\
100 & 25.0 & 98.1 \\
200 & 15.5 & 97.6 \\
250 & 10.0 & 96.3 \\
400 & 6.25 & 89.8 \\
\hline
\end{tabular}

\begin{tabular}{|c|c|c|}
\hline \multicolumn{3}{|c|}{$\begin{array}{c}\text { TABLE V } \\
\text { Analytical Figures of Merit } \\
\text { of the SPE Method }\end{array}$} \\
\hline Parameter & ICP-OES & $\begin{array}{c}\text { SPE- } \\
\text { ICP-OES }\end{array}$ \\
\hline $\begin{array}{l}\text { Linear range } \\
\left(\mathrm{ng} \mathrm{mL}^{-1}\right)\end{array}$ & $50-1500$ & $1.0-30$ \\
\hline $\begin{array}{l}\text { LOD } \\
\qquad\left(\mathrm{ng} \mathrm{mL}^{-1}\right)\end{array}$ & 3.9 & 0.06 \\
\hline $\begin{array}{l}\text { LOQ } \\
\qquad\left(\mathrm{ng} \mathrm{mL}^{-1}\right)\end{array}$ & 13 & 0.21 \\
\hline RSD (\%) & 8.1 & 6.6 \\
\hline Slope & 6.9 & 325 \\
\hline Intercept & -130 & -142 \\
\hline $\mathbf{r}^{2}$ & 0.9996 & 0.9997 \\
\hline
\end{tabular}

volume on the uptake of $\mathrm{Sn}^{2+}$ was studied under optimum conditions ( $\mathrm{pH}$, eluent, etc.). The results in Table IV show that the uptake of $\mathrm{Sn}^{2+}$ was quantitative for volumes of 50-250 mL. At higher volumes, the uptake of $\mathrm{Sn}^{2+}$ decreased. The uptake value for a 400-mL sample volume was determined as $89.8 \%$. Therefore, the preconcentration factor of 50 was obtained for an elution volume of $5.0 \mathrm{~mL}$ and sample volume of $250 \mathrm{~mL}$.

\section{Analytical Figures of Merit}

In solid phase extraction studies, the potential regeneration and stability of the column is a very important parameter to evaluate the biosorbent which can guarantee its widespread application in industry. The stability of the solid phase extraction column shows that the uptake of $\mathrm{Sn}^{2+}$ ion was stable up to at least 30 biosorption-elution cycles with the recovery for the $\mathrm{Sn}^{2+}$ ions greater than $95.0 \%$ (Figure 3).

The analytical figures of merit of the developed SPE method are presented in Table $\mathrm{V}$. The limit of detection (LOD) and limit of quantification (LOQ) values were calculated from the ratio of three and 10 times of the standard deviation of the lowest concentration in the linear range to the slope of the linear calibration plot, respectively. The relative standard deviation (RSD) was $6.6 \%$. By considering the 250.0 $\mathrm{mL}$ initial and $5.0 \mathrm{~mL}$ final volume,

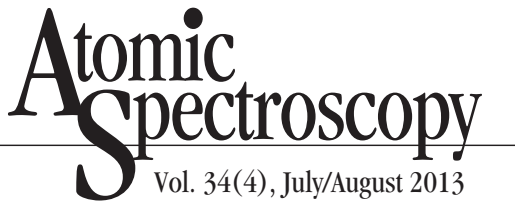

the preconcentration factor was calculated as 50.0 for $\mathrm{Sn}^{2+}$. The sensitivity of the ICP-OES determination of $\mathrm{Sn}^{2+}$ improved 47.1 times. This was calculated using the slope ratio of the linear calibration plot of the SPE-ICP-OES method in comparison to ICP-OES without the SPE method. The LOD value obtained in this study was $0.6 \mathrm{ng} \mathrm{mL}^{-1}$ which is comparable with the values reported in the literature as follows: 1.1 and $0.7 \mathrm{ng} \mathrm{mL}^{-1}$ for solid and liquid samples, respectively, by preconcentration on Saccharomyces cerevisiae and determination by ICP-OES (1), $8.4 \mathrm{ng} \mathrm{mL}^{-1}$ by FAAS after micelle mediated extraction (14), $0.04 \mathrm{ng} \mathrm{mL}^{-1}$ by quartz atom traphydride generation AAS (31), $2.86 \mathrm{ng} \mathrm{mL}^{-1}$ by cloud point extraction before AAS measurement (2), $0.012 \mathrm{ng} \mathrm{mL}^{-1}$ by graphite furnace AAS after cloud point extraction (4), and $1.5 \mathrm{ng} \mathrm{mL}^{-1}$ by electrochemical hydride generation atomic fluorescence spectrometry using polyaniline-modified lead cathode (32).

The effects of possible interfering ions on the preconcentration of Sn were investigated. For this purpose, individual solutions of $\mathrm{Na}^{+}$, $\mathrm{K}^{+}, \mathrm{Ca}^{+2}, \mathrm{Mg}^{+2}, \mathrm{Fe}^{+2}, \mathrm{Cu}^{+2}, \mathrm{Ni}^{+2}$, $\mathrm{Co}^{+2}, \mathrm{Hg}^{+2}, \mathrm{Cd}^{+2}, \mathrm{Cr}^{+3}, \mathrm{Sb}^{+3}, \mathrm{Bi}^{+3}$ and $\mathrm{Al}^{+2}$ at concentrations of 10 , 100, and 1000 times higher than the concentration of $\mathrm{Sn}^{2+}$ were subjected to the SPE procedure. The

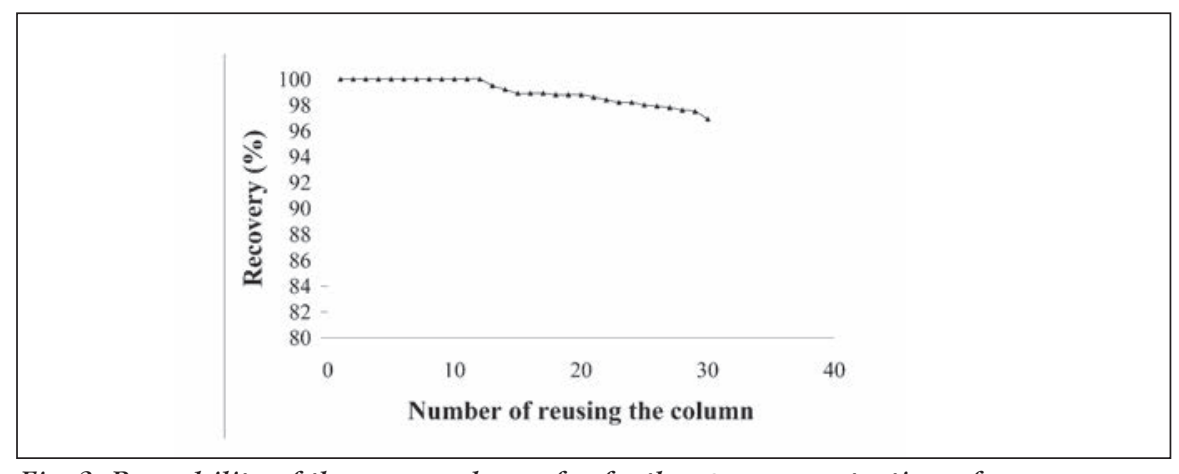

Fig. 3. Reusability of the same column for further preconcentration of $10.0 \mathrm{ng} \mathrm{mL}^{-1}$ of $\mathrm{Sn}^{2+}$. 
results show no significant decrease in the recovery of $10.0 \mathrm{ng} \mathrm{mL}^{-1}$ of $\mathrm{Sn}^{2+}$, even when the concentrations of the ions were 1000 times higher than those of Sn. Additionally, a solution was prepared from the mixture of the above-mentioned ions where the concentrations were also 1000 times higher than that of $\mathrm{Sn}$. The recovery value for $\mathrm{Sn}$ was $95.6 \pm 1.4 \%$. It can be concluded that the developed method has selectivity in additon to sensitivity for Sn and could easily be applied to real samples for the determination of their Sn concentrations.

The accuracy of the method was investigated through the analysis of certified reference material NWTM26.3 Fortified Water sample. A sample amount of $250 \mathrm{~mL}$ was subjected to the SPE procedure and the concentration of $\mathrm{Sn}^{2+}$ was found as $5.7 \pm 0.2 \mathrm{ng} \mathrm{mL}^{-1}$, while it was certified as $5.9 \mathrm{ng} \mathrm{mL}^{-1}$. Thus, it can be concluded that the method can be applied to real samples. The RSD value was found as low as $3.5 \%$.

The developed method was also applied to real samples to determine the applicability of the method. For this purpose, three sampling points on the Tigris River were selected and the SPE method was applied to the water samples for preconcentration of $\mathrm{Sn}^{2+}$. The results presented in Table VI show that the mean $\mathrm{Sn}^{2+}$ concentration was $10.0 \mathrm{ng} \mathrm{mL}^{-1}$.

TABLE VI

Concentrations of $\mathrm{Sn}^{2+}$ in the Water Samples From the Tigris River

\begin{tabular}{lc}
\hline $\begin{array}{l}\text { Sampling } \\
\text { Point }\end{array}$ & $\begin{array}{c}\mathrm{Sn}^{2+} \\
\left(\mathrm{ng} \mathrm{mL}^{-1}\right)\end{array}$ \\
\hline Hevsel & $10.1 \pm 0.5$ \\
Ongözlü & $10.0 \pm 0.7$ \\
DicleKöprü & $9.9 \pm 0.6$ \\
\hline
\end{tabular}

Different studies have been published on the $\mathrm{Sn}$ concentrations in water samples and include the following: Xijun et al. (33) reported that the concentration of $\mathrm{Sn}^{2+}$ in a real wastewater sample was found to be $0.72 \pm 0.02 \mu \mathrm{g} \mathrm{mL}^{-1}$ (33). Caldorin and Menegario (1) found the $\mathrm{Sn}^{2+}$ concentrations in three river water samples at 19, 18, and $40 \mathrm{ng}$ mL-1 (1), respectively. Alp et al. (10) reported $\mathrm{Sn}^{2+}$ concentrations in spring and mineral water at $0.63 \pm 0.03,1.70 \pm 0.12 \mathrm{ng} \mathrm{mL}^{-1}$, respectively, determined by in situ trapping of stannane on a resistively heated iridium-treated tungsten coil surface. The Yuan et al. (34) study found $\mathrm{Sn}^{2+}$ concentrations of 0.36 and $0.12 \mathrm{ng} \mathrm{mL}^{-1}$ in sea and river water, respectively, whereas the concentration of $\mathrm{Sn}^{2+}$ in a tap water sample was lower than the detection limit (LOD = $0.012 \mathrm{ng} \mathrm{mL}^{-1}$ ).

\section{CONCLUSION}

An alternative method was developed for the preconcentration of trace levels of $\mathrm{Sn}^{2+}$ by solid phase extraction (SPE). Helvella leucopus was used as a fungal biosorbent for the preconcentration of $\mathrm{Sn}^{2+}$ prior to its determination by inductively coupled plasma optical emission spectrometry (ICPOES). The important experimental parameters in the developed SPE method were optimized. Concentrations of $\mathrm{Sn}^{2+}$ in river water samples from Turkey were determined after the developed SPE method was applied. The sensitivity of ICPOES was improved 47.1 times in comparison to using conventional methodology. The applicability of the method was validated by analysis of the certified reference material NWTM-26.3 Fortified Water sample with satisfactory results.

Received May 7, 2013.

\section{REFERENCES}

1. R. Caldorinand and A.A. Menegario, Microchim. Acta 157, 201 (2007).

2. S. Ulusoy, H.I. Ulusoy, M. Akçay, and R. Gürkan, Food Chem. 134, 419 (2012).

3. Q. Zhang, H. Minami, S.Inoue and I. Atsuya, Fresenius J. Anal. Chem. 370, 860 (2001).

4. E. Kilınc, F. Aydin and M.Z. Duz, At. Spectrosc. 33, 173 (2012).

5. T. Madrakian and F. Ghazizade, J. Braz. Chem. Soc. 20,1535 (2009).

6. O.A. Zaporozhets, L.S. Ivanko, I.V.Marchenko, E.V. Orlichenko and V.V. Sukhan, Talanta 55, 313 (2001).

7. K.S. Abou-El-Sherbini, M.M. Hassanien and I.M.M. Kenawy, Sep. Sci. Technol. 42, 3447 (2007).

8. H.H.V. Costa, G.F. Lima, L.R. Nacano and C.R.T. Tarley, Water Air Soil Poll. 217, 557 (2011).

9. K. Agrawal, K.S. Patel, K. Shrivas,V.K. JainandF. Khan, J.Hazard. Mater. 164, 95 (2009).

10. O. Alp and N. Ertas, Talanta 81, 516 (2010).

11. P. Bermejo-Barrera, R.M. AnlloSendín, M.J. Cantelar-Barbazán and A. Bermejo-Barrera, Anal. Bioanal. Chem. 372, 837 (2002).

12. S. Özdemir, V. Okumuş, A. Dündar and $\mathrm{E}$. K1lınç, Microchim. Acta 180, 719 (2013).

13. Z. Moldovan and L. Vlidescu, Anal. Chim. Acta 338, 231 (1997).

14. M.B. Gholivanda, A. Babakhaniana and E. Rafieeb, Talanta 76, 503 (2008).

15. S. Özdemir, R. Gul-Guven, E. Kilinc, M. Dogru and S. Erdogan, Microchim. Acta 169, 79 (2010).

16. S. Özdemir, S. Erdogan and E. Kilinc, Microchim. Acta 171, 275 (2010).

17. S. Özdemir and E. Kilinc, Microchim. Acta 178, 389 (2012).

18. S. Özdemir, V. Okumuş, E. Kılınç, H. Bilgetekin, A. Dündar and B. Ziyadanogulları, Talanta 99, 502 (2012). 


\section{A $_{\text {Spectroscopy }}^{\text {tomic }}$ \\ 1 Vol. 34(4), July/August 2013}

19. S. Ozdemir, E. Kilinc,A. Poli, B. Nicolaus and K. Guven, Chem. Eng. J. 152, 195 (2009).

20. M. Imamoglu and V. Gunes, At. Spectrosc. 33, 205 (2012).

21. K.O. Saygi, M. Tuzen and M. Soylak, L. Elci, J. Hazard. Mater.153, 1009 (2008).

22. Y. Jiang, H. Zhang, Q. He, Z Hu and X. Chang, Microchim.Acta 178, 421 (2012).

23. S. Baytak, A. Koçyiğit and A.R. Türker, Clean-Soil Air Water 35, 607 (2007).

24. L. Alcalde-Isorna, M.C. BarcielaAlonso and P. Bermejo-Barrera, At. Spectrosc. 32, 324 (2011).

25. Q. He, X. Chang, X. Huang and Z. Hu, Microchim.Acta 160, 147 (2008).

26. F. Sun, W. Sun, H. Sun and J. Ni, Chem. Eng.J.172, 783 (2011).

27. N. Yeddou-Mezenner, Desalination 262, 251 (2010).

28. H. Bağ, A.R. Türker, M. Lale and A. Tunçeli, Talanta 51, 895 (2000).

29. O. Yildız, D. Citak, M. Tuzen and M. Soylak, Food. Chem. Toxicol. 49, 458 (2011).

30. Y. Liu, Y. Guo, S. Meng, F. Feng and X. Chang, Microchim. Acta 157, 209 (2007).

31. H. Matusiewicz and M. Krawczyk, Anal.Lett. 43, 2543 (2010).

32. X. Jiang, W. Gan, L. Wan,Y. Deng, Q. Yang and Y. He, J.Hazard. Mater. 184, 331 (2010).

33. C. Xijun, S. Zhixing, Y. Dong, L. Xingyin and G. Bolin, Anal. Lett. 30, 2611 (1997)

34. C. Yuan, G. Jiang, B. He, and J. Liu, Microchim. Acta 150, 329 (2005). 